\title{
Types of Indonesian Sentences by Ten Years Old Receptive Child
}

\author{
Yeni Monalisa Gultom
}

Universitas Negeri Medan

Email: monalisa.bumi08gmail.com

\begin{abstract}
Sentence is very meaningful collection of word, where the sentence can state an idea or idea in full. sentence is a benchmark for child in their language skills. in writing it can be started with capital letter, end with a full stop, question mark, or exclamation mark. there are several types of Indonesia sentence that will be discussed namely declarative sentence, interrogative sentence, imperative sentence, and interjective sentences. a child is said to be receptive based on several criteria and indicators. This research conducted in a qualitative research, the source of the data from transcribe utterances conversation from daily activity. Technique of the data collection is recording, transcribing the sentence, verifying and classifying. this study found that ten years old child were more dominant in interrogative that is 26 data $(34,6 \%)$ sentence and very minimal in declarative sentences that is 9 data $(12,1 \%)$.
\end{abstract}

Keywords: Indonesian sentences, receptive, ten years old child.

\section{INTRODUCTION}

The Parents are very impressed with the growth of language in each child, and is a matter of great concern in every development, and often makes a benchmark of the abilities of the child. Where the child can produce sentence with perfect grammar and is often implied that the child has mastered the language well. Language also refers to cognitive abilities. Before the child produces language, he must first produce a sentence. Many definitions of the sentence has been created. Harimurti Kridalaksana (1993:21) states that language is a symbol system sounds an arbitrary language that allows people to work together, interact and identify. The sentence in question in here is a syntactic unit composed of the fundamental constituents, which conjunctions when needed, and be accompanied by a final intonation (Chaer, 2009: 44). There are several sentences in Indonesian, namely declarative, interrogative, imperative, and interjective sentences. And in this study, it will be discussed to determine the quality of the acquisition of sentences from ten-year-old children.

From the explanation above, it can be concluded that the sentence is a very meaningful collection of words. Where the sentence can state an idea or idea in full. Sentence is a benchmark for a child in his language skills. In writing it can be started with a capital letter, and ended with a full stop, question mark, or exclamation mark, and for interjective sentence the language pattern is more dominant than body language itself.

\subsection{Problems of the study}

It is important to make problem of the study, research problem is a statement about an area of concern, a difficulty to be eliminated. The problem of the study in this research:

What types of Indonesian sentences are acquired by ten years old receptive child?

\subsection{Objective of the study}

To mention and analyze the type of sentence in bahasa Indonesia obtained by a 10 -year-old receptive child

\section{CHAPTER II REVIEW LITERATURE}

\subsection{Language Acquisition}

Language acquisition is the applicable processes in the brain of a child when acquiring language. There are two processes that occur when a child is being gained their first language, competence and performance. Both of these processes are two different processes. Competence is the mastery of grammar which takes place unconsciously. The process of this competence be condition for the occurrence of the performance consist of two processes, namely the process of understanding and the publishing process or the process of making sentences. The process understanding involves the ability to observe or ability in thinking sentence heard. While publishing involves the ability of issuing or publishing the sentences yourself. In line with theory of Chomsky 
(1957-1965), a component that includes that three component of a grammar that is a component of synatx, semantics and phonology components.

The above statement showed that language acquisition takes place in the brain of children when he gained his first language or mother tongue. Language acquisition usually distinguished by language learning. Learning the language associated with the processes that occur when a child learning a second language after he gained his first language. Thus, language acquisition with respect to the first language, while learning a second language with respect to language.

\subsection{Children's Language Development Stage}

All children seem to go through a series of language stages as they acquire language. The age of the child when it reaches these stages can be different, but the sequence of stages of language proficiency seems to be the same for every child. According to Aitchison (1984), children's language proficiency stage looks like the following table.

Table 1. Stage of children language development

\begin{tabular}{|l|l|}
\hline Child Development Stage & Umur \\
\hline Cry & Lahir \\
\hline Snoring & 6 Months \\
\hline Babble & 6 Months \\
\hline intonation pattern & 8 Months \\
\hline one word speech & 1 year \\
\hline two words speech & 18 Months \\
\hline word inflection & 2 years \\
\hline $\begin{array}{l}\text { interrogative and denial } \\
\text { sentences }\end{array}$ & $21 / 4$ years \\
\hline $\begin{array}{l}\text { Rare and Complex } \\
\text { Construction }\end{array}$ & 5 years \\
\hline Mature speech & 10 years \\
\hline
\end{tabular}

\subsection{Sentence}

Many definitions of the sentence has been created. The sentence in question in here is a syntactic unit composed of the fundamental constituents, which conjuctions when needed, and be accompanied by a final intonation (Chaer, 2009: 44). Based on the above definitionn, it basically consists of the fundamental constituents of the sentence and intonation final, because conjuntions there are only when necessary. Basic constituents usually a clause. Words and phrases can also be regarded as a basic constituent, in the phrases "short answer" or a minor sentence is certainly not "free word" (Chaer, 2009: 44). It is different if the constituens are essentially in the form of the clause, it can form a free sentence.

Intonation base which is an important condition for the establishment of a sentence can be either intonation declarative (use a dot), intonation interrogative (use question mark), intonation imperative (use exclamation marks), intonation interjective (use exclamation marks) without final intonation is a clause would not be a sentence.

Formally, sentence is divided into news sentences, interrogative sentence and sentence orders. Conventionally sentence news used to tell somtehing (information), interrogative sentence to as for something, and command sentence to express a command, invitation, request or petition.

\subsubsection{Sentence in Bahasa Indonesia}

According to Chaer, 2009: 44) "The division of sentence is based on term of content is this division based on the content or man date to be conveyed to the listener. "Based on the term of content / speech, sentence upon sentence is distinguished in declarative sentence, interrogative, imperative and interjective.

\subsubsection{Declarative Sentence}

According to (Chaer, 2009: 187) "Declarative sentence is a sentence that it delivered a statement to another person." This declarative sentences do not require a response either verbally or with action. However, it could be given the comments by the audience when deemed necessary.

Declarative sentence in this mode can be divided into sentences:

1. Only to tell factual information regarding the surrounding nature or experience of the speaker. Example : Outside rain again

2. To tell decisions or judgments. Example : The food is delicious.

3. To declare the agreement, warning, advice and so on. Example: You have to be careful on arrival in London, We hope you ${ }^{\text {ee }} 1$ accept this decision.

4. To express his congratulation on a succesful or speech concerned over a misfortune. Example: Our condolences over the death of your parents.

5. To give an explanation, description or details to someone. Example: I explained to you that he is innoncent.

\subsubsection{Interrogative Sentence}

According to (Chaer, 2009: 189) "interrogative sentence are sentences that are expecting their answer verbally." This answer may be the recognation, description, reason or opinion of the listener or reader.

For the example:

1. What is your name?

2. Why does that man run?

3. How price of cooking oil now?

From the reactions of the answer given their distinguished: 
1. Sentence interrogatory requesting the recognition of a "yes or "no"

2. The sentence interrogative who inquired about one of the elements (functions) of the sentence.

3 . Interrogative sentence that ask a reason.

4. Interrogative sentence that ask for opinions or ideas of others.

5. The interrogative sentences homologate.

\subsubsection{Imperative Sentence}

According to (Chaer, 2009: 197) "imperative sentence is sentences that ask the listener or reader to take an action." Imperative sentence is a sentence that is set up to provoke the response in the form of action. Imperative sentences have the feature:

1. Intonation marked low tone at the end of the sentence.

2. The use of emphatic particles, expectation, demands and restrictions.

3. The composition of the inversion so that it becomes not always unfold predicate-subject if needed.

\subsubsection{Interjective Sentence}

According to (Chaer, 2009: 188) "interjective sentence is a sentence to expres emotion." This express such as: shocked. Suprised, amazed, angry, sad, exasperated, frustrated, etc. Finally, this thesis will specifically discuss the use of declarative sentences, imperative sentences, interrogative sentences, and interjective sentences.

Many definitions of the sentence has been created. The sentence in question in here is a syntactic unit composed of the fundamental constituents, which conjuctions when needed, and be accompanied by a final intonation (Chaer, 2009: 44). Based on the above definitionn, it basically consist of the fundamental constituents of the sentence and intonation final, because conjuntions there are only when necessary. Basic constituents usually a clause. Words and phrases can also be regarded as a basic constituent, in the phrases "short answer" or a minor sentence is certainly not "free word" (Chaer, 2009: 44). It is different if the constituens are essentially in the form of the clause, it can form a free sentence.

Intonation base which is an important condition for the establishment of a sentence can be either intonation declarative (use a dot), intonation interrogative (use question mark), intonation imperative (use exclamation marks), intonantion interjective (use exclamation marks) without final intonation is a clause would not be a sentence.

Formally, sentence is divided into news sentences, interrogative sentence and sentence orders. Conventionally sentence news used to tell somtehing (information), interrogative sentence to as for something, and command sentence to express a command, invitation, request or petition.

\section{RESEARCH DESIGN}

This research conducted in a qualitative research. Qualitative descriptive type of research means that this research carefully describes the linguistic phenomena as well as visual image phenomena based on the facts of real language and image. Bogdan and Biklen (1998:4) conclude five characteristics of qualitative research namely: 1) Naturalistic, qualitative research has actual 'setting' functions as the data source and the analyst is the main instrument, 2) descriptive in nature, the data collected take the form of words or pictures, 3) concern with process, the process is more important than the result, 4) the data are analyzed inductively, and 5) 'the meaning' is the main focus.

Bogdan and Biklen (1992) assert that descriptive means the data collected in the form of words rather than number. Descriptive qualitative tried to analyze the data with all their richness as closely as possible to the form in which the researcher record and transcribe and the written result of the research.

The problems is about the sentences acquisition by ten year old Reseptive child. The types of this study is observational the data will be gathered by applying (participant) observation. The focus of this study is to identify the sentences items acquired by ten year old reseptive child.

\subsection{Data and Source of the Data}

Bogdan and Biklen (1998:106) refer data to the rough materials collected from the world to be studied including interview transcripts, observation, field notes official document. The data of this research is transcribe utterances conversation from daily activity like watching movie, talking with member, playing outside. The source of the data from the ten years old child named Yeriel. Yeriel is an only child, Yeriel did not have any sibling, his mother works at a state owned bank, and his father is a manager in a private company. Yeriel was guarded by his opung from morning to night. Yeriel is a unique child and looks different from children in general.

\subsection{Technique of Data Collection}

The data were collected in two periods of observation, in order to get the development of words acquired by ten year old child. There were some steps that has been done by the writer to get the data as follows;

1. Recording the children conversation when Yeriel were playing, learning, watching TV, talking with family members

2. Transcribing the sentences types which found in conversation acquired by ten year old child.

3. Displaying the data in table to get an easily understood configuration. This will be numerously useful to visualize mutual relation among the data obtained, and

4. Verifying and drawing conclusion on the data by selecting, summarizing, and conceptualizing the data througly and systematically. 
5. Classifying the words acquired by the children from the result of transcription based on its categories.

\subsection{Instrument Data Collection}

Research instrument is a tool or equipment used in collecting data. A recorded had been used as the instrument for collecting the dara. The data of this study was the children's sentence that had been collected from the transcript of recorded observation, interview and field notes. In order to get the data, the observation was held in researcher's or child'shouse. The children words were recorded obtained through daily observation in different context such as when playing, wathcing TV and do some home activities.

\subsection{Technique of Data Analysis}

The data will be analyzed by interactive model classified officially by Miles, Huberman \& Saldana (2014). According to Miles and Huberman there are; data condensation, data display, and drawing conclusion/ verifying.

\subsubsection{Data condensation}

Data condensation refers to the process of selecting, focusing, simplyfiying, abstracting and transforming the raw data.

a. Selecting

The sentence produced by child will be selected to be analysed based on utterances in the term of content such as declarative, interrogative, imperative and interjective.

b. Focusing

Focusing means the researcher paid attention to the appropriate data. The selected data then categorizing based on the types of sentences and receptive language disorder.

c. Simplifying

Means to make the data simpler or easier to understand by grouping of terms based on the types of sentences.

d. Abstracting

The data which as analized abstracted to get the findings of the research well. The word produced by receptive child.

e. Transforming

In this part, the researcher will transform the data into display with the analysis word acquired by receptive child were the sentences item.

\section{RESULT AND DISCUSSION}

\subsection{Data Analysis}

This research the data is sentences, that acquired by the ten years old child. The data was taken from utterences which were produced by the ten years old child which have receptive language, while the subject were playing, and talking with his family members. In data analysis, the researcher followed the steps from miles, huberman (2014).

\subsubsection{Types of Indonesian Sentences Acquired by Ten Years Old Child with Receptive Language}

The data was taken from the subject's utterance through two month observation in Mei until Juli. At the age of ten the childrent have acquired sentences namely declarative sentence, interrogative sentence, imperative sentence, and interjective sentence. Children aged ten years based

Table 2. Declarative Function

\begin{tabular}{llc}
\hline No & \multicolumn{1}{c}{ Function } & $\begin{array}{l}\text { Frequency } \\
\text { Percentage }\end{array}$ \\
\hline 1. & To tell Decision & 5 \\
2. & To Declare Warning & 2 \\
3. & To Desrcribe Something & 2 \\
\hline & Total & 9 \\
\hline
\end{tabular}

on the theory of children's language development should already have perfect or matured sentence pronunciation. But based on the subject, this ten year old child is different because it is identified as having a language disorder, namely receptive language disorder. The character of a receptive person has been discussed in the previous chapter, that are using language correctly before, lack of ability to describe something, feeling embarrassed, from one topic to another, vocabulary limitations, poor social language, difficult to use sentences.

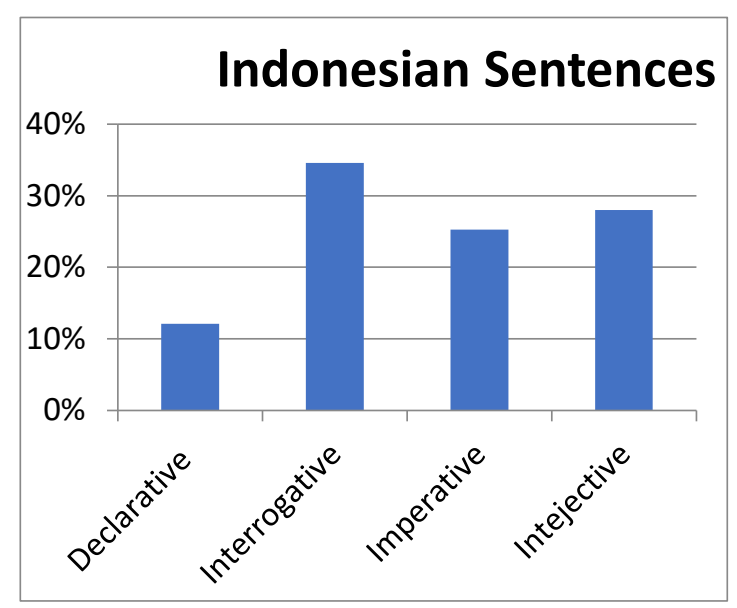

Figure 1. Sentences Diagram

In this research About question one, therefore interrogatives are much more than other sentences that is 26 data $(34,6 \%)$. Because at their age, which supports children in asking a lot of questions, the question that is often used is the question "why". The second is an interjective sentence with the form of expression where the most frequently used are angry and surprised that is 
21 data (28\%). And the third is the imperative sentence and the one that comes out the most is imperative for commands, warnings and advice that is 19 data $(25,03 \%)$. And the last one is Declarative sentences 9 data $(12,01)$ the most frequently is To make decision. Because seeing the ten-year-old child is a child who doesn't care and rarely declares something.

\subsubsection{Declarative Sentence}

Declarative sentences used to make statements in the form of facts or opinions. Declarative sentences are the most frequently used sentence types to tell decision, to declare warning, to description something.

The conversation below is a form of declarative sentence to describe or to give details about someone with receptive characteristic. This conversation was taken while we were looking at a photo. The situation below occurred during the day when Yeriel's son was lying on the sofa watching television. where mona as a niece asked Yeriel about the face comparison between her brother named Japet and Yeriel's face, to make it easier for the author to make it symbolize M (Mona), I (Yeriel).

Mei , 27 2021 at home in the living room :

M : Iyel, Mana Lebih Ganteng Abang Japet atau Iyel?

(Iyel, which is more handsome, brother Japet or Iyel?)

I : emh, emh, Apa kak kenapa kak?

(emh, emh, what are you, why are you?)

$M \quad$ : Iya kamu jawab, bandingkan wajah iyel dengan bang japet, lebih tampan siapa?

(Yes, you answer, compare the face of iyel with bang japet, who is more handsome?)

I : Lebih tampan ? lebih tampan, lebih tampan kak ? emh, iyel sedikit ganteng dari abang . hidung abang lebih mancung, sedang iyel sedikit besar, tapi wajah iyel seperti mami, mami kata iyel itu ganteng, jadi iyel sedikit ganteng dari abang.

(More handsome? more handsome, more handsome sis? emh, iyel is a little more handsome than my brother. Brother's nose is sharper, while Iyel's is a little big, but Iyel's face is like Mami, Mami said Iyel is handsome, so Iyel is a little more handsome than Brother.)

M : baiklah,.. (oke)

From the conversation above, it can be seen that the child is describing someone's face, " iyel sedikit ganteng dari abang " in the sentence for a ten year old child it sounds less than perfect with the normal use of the word "sedikit" a ten year old child will say " abang japet lebih ganteng dari pada iyel". In the explanastion of receptive language one of the characteristics of a receptive person is to repeat sentences is heard when a ten year old child repeats the sentence many times "Lebih tampan, lebih tampan, lebih tampan" and the lack of grammar that a ten year old child has that sounds from the word "sedikit"
The next conversation is a form of declarative sentence to say a decision and declare agreement. The conversation was taken while going to lunch in the kitchen, when Mona and Yeriel are chatting at the dinner table and are about to order lunch through the app

Mei, $\mathbf{2 8}^{\text {th }}$ 2021, at the kitchen in the afternoon:

M : abang kita makan siang apa ya? (what do we have for lunch bro?)

I $\quad$ : Makan siang apa kak (What do you have for lunch?)

M : iya iyel pilih mana makan mie ayam atau bebek goring?

(Yes, Iyel, which one do you prefer to eat, chicken noodles or fried duck?)

I : Bagaimana dengan mie ayam kak, sepertinya lebih enak jika panas.

(How about the chicken noodles, Sis, it looks better if hot.)

M : oke mie ayam ya (ok chicken noodle)

From the conversation above, it can be seen that the ten-year-old made the decision to choose his lunch, and agreed when it was offered. Normally a ten-year-old child will say briefly without any further questions, "mie ayam saja kak." The use of standard sentences is also a characteristic of a receptive child, as can be seen from the sentence "Bagaimana dengan mie ayam, sepertinya lebibh enak jika panas"

\subsubsection{Interogative Sentence}

An interrogative sentence is a sentence that asks a direct question and always ends with a question mark, with what, where, who, how, when.

Table 3. Interogative Fuction

\begin{tabular}{llcc}
\hline No. & Function & Frequency & percentage \\
\hline 1. & What & 7 & $27 \%$ \\
2. & Where & 6 & $23 \%$ \\
3. & Who & 4 & $15,35 \%$ \\
4 & When & 4 & $15,35 \%$ \\
5. & How & 5 & $19,3 \%$ \\
\hline & Total & 26 & $100 \%$ \\
\hline
\end{tabular}

From the table above, it can be seen that the total number of each function obtained, where what questions have more numbers than the others, namely 7 data (27\%), secondly there are 6 data questions (23\%), who 4 data $(15.35 \%)$, when as much as 4 data $(15.35 \%)$ and the last is how as much as 5 data (19.3\%).

Interogtaive is used to ask reasons, ask about opinions, below is a conversation in the form of interrogative sentences to ask reasons, this conversation was taken while making milk at night. to make it easier for the author to make it symbolize O (Opung), I (Yeriel). Juni, $02^{\text {nd }} 2021$ at kitchen, in the evening 


\begin{tabular}{|c|c|}
\hline & $\begin{array}{l}\text { : Awas panas bang } \\
\quad \text { (Beware it's hot bang) }\end{array}$ \\
\hline & $\begin{array}{l}\text { apa panas pung? } \\
\text { (is it hot?) }\end{array}$ \\
\hline & $\begin{array}{l}\text { air nya lah panas } \\
\text { (the water is hot })\end{array}$ \\
\hline & $\begin{array}{l}\text { Cuaca hari ini panas pung, sedikit hujan, } \\
\text { itu susu iyel pung? } \\
\text { (Today's weather is hot, it's raining a little, } \\
\text { is that Iyel Pung's milk?) }\end{array}$ \\
\hline & $\begin{array}{l}\text { apa kamu ini, tidak nyambung } \\
\text { (what are you, not connecting) }\end{array}$ \\
\hline & $\begin{array}{l}\text { : susu kenapa harus pakai air panas pung? } \\
\text { (Why do you have to use hot water for milk?) }\end{array}$ \\
\hline & $\begin{array}{l}\text { Ya biar larut, kamu belajar atau tidak } \\
\text { (Yes, let it be late, do you study or not) } \\
\text { : Oh okey pung }\end{array}$ \\
\hline
\end{tabular}

The conversation above, it can be seen that a ten-year-old child does interrogative sentences in his own way to ask about the reason why it can be seen from the sentence "susu kenapa pakai air panas pung" from the sentence a ten-year-old child asks why milk should use hot water, and in answered by Opung with the sentence "agar larut", in this case the declarative sentence has a role to ask for a reason. Receptive interference can be seen from one of the characteristics, namely jumping from topic to topic, in this case it can be seen in the sentence "Cuaca hari ini panas pung, sedikit hujan" Previously, Opung and a ten year old child discussed milk and hot water, but the child jumped, and talk about the weather that day.

The next conversation is an interrogative sentence to ask your opinion, this conversation was taken while watching tv in the living room

Juli, 8 2021, at living room

I : pung bagaimana dengan pendapat opung, siapa yang lebih pinter kah, orang Indonesia atau orang singapura? (pung according to Opung, who is smarter, Indonesian or Singaporean?)

o $\quad$ : kamu searching lah di google (you search on google)

I : (sambil memegang hp) Menurut google singapur jauh lebih cerdas dari pada Indonesia

(while holding cellphone) According to Google, Singapore is much smarter than Indonesia)

$O$

: ya sudah.

(yes)

The next conversation is an interrogative sentence to ask your opinion, this conversation was taken while watching tv in the living room. From the conversation above, it can be seen that a ten-year-old child asks Opung for opinions, it can be seen from the sentence "menurut opung siapa yang pintar" this sentence is an interrogative sentence to ask for opinions. Normally a ten year old child will ask simple and easy questions, normally a ten year old child will ask "Who is smarter in Singapore or Indonesia?" Receptive disorders are heard from how the child is difficult to ask and describe his questions, lack of ability to describe something, so the sentences sound very standard and sound wasteful in their use.

\subsubsection{Imperative Sentence}

An imperative sentence is a sentence type that is used to make commands, warnings, instructions, advice, and requests.

Table 4. Imperative Frequency

\begin{tabular}{lllc}
\hline No. & Function & Frequency & Percentage \\
\hline 1. & To make & 4 & $21,05 \%$ \\
& Command & & \\
2. & To Give & 4 & $21,05 \%$ \\
& Warnings & & \\
& Making & & $10,45 \%$ \\
3. & Instruction & 2 & $21,05 \%$ \\
4. & Advice & 4 & $26,4 \%$ \\
5. & Request & 5 & $100 \%$ \\
\hline & Total & 19 & \\
\hline
\end{tabular}

From the data above, it can be interpreted that the highest Imperative frequency is found in requests, namely 5 data (26.4\%), both to make commands are 4 data $(21.05 \%)$, To give warnings 4 data $(21.05 \%)$, giving advise 4 data $(21.5 \%)$, and the last one in making instructions was only 2 data (10.45\%).

Below is a conversation of a ten year old child how the child gives orders to his brother in receptive language, the conversation below is taken while in the room in the morning

Juli 07, 2021, in the Yeriel badroom

Iyel : Kak, ambilkan iyel baju ?(sambal keluar masuk kamar)

(Sis, get me some clothes? (while going in and out of the room))

kakak : apa sih baju apa? mau apa?

(what are you wearing? What do you want?)

Iyel : Kak baju iyel itu, eeh, emh, kak cepat, sekarang!

(Sis, that iyel t-shirt, eeh, emh, sis hurry up, now!)

Kkak : kamu merintah gak jelas, gak sopan lagi

(you command is not clear, it's not polite anymore)

Iyel : baju iyel lemari dalam ambil, iyel suruh sekarang! (menangis)

(Iyel's clothes in the closet are taken, Iyel orders now! (cry))

Kakak : iyel, perbaiki, pakai kata tolong, jangan nangis (sambal mengajarkan kalimat yang baik) 
(iyel, fix it, use the word please, don't cry (sambal teaches good sentences)

From the conversation above, it can be seen that ten-year-old children are not yet mature in using or saying imperative sentences, where in general, in giving orders, ten-year-olds have very good sentences. Imperfections in the pronunciation of imperative sentences can be seen from the sentences "Sis clothes iyel, kak fast, now!) and "Iyel clothes in the cupboard to take, iyel order now", these sentences are command sentences from a ten year old child with an emphasis on a command tone, the child crying because my sister didn't move as she wanted. The use of imperfect sentences from the ten-year-old child is very clear, the receptive language can be seen from the lack of vocabulary that the child has and uses inappropriate grammar.

The next imperative sentence we can see in the conversation below, this conversation was taken in the afternoon; Opung and Kaka were talking in the kitchen Mei $15^{\text {th }}, 2021$ during the day in the kitchen

Iyel : (tiba tiba menghampiri) opung dan kaka sedang apa?

((suddenly approached) what are you and brother doing?)

Opung : chit chat lah

Iyel : opung dan kakak sedang gosipin iyel yeee

(Opung and sister are gossiping about iyel yeee)

Mona : pede banget kamu

(you are confident boy)

Opung : eh gossip gossip, memang kamu tau apa itu gossip, asal aja

(uh gossip gossip, do you know what gossip is, just so long

Iyel : opung itu sedang gossip,uh,emh,eeh (sambal menunjuk) opung sedang gossiping dengan kakk

(Opung is gossiping, uh, emh, eeh (same pointing) Opung is gossiping with sis)

Opung : coba jelasin sama kami apa itu gossip?

(try to explain to us what is gossip?)

Iyel : pung,pung,pung, jangan Gosip (sambil menunjuk nunjuk) itu tidak baik, nanti opung dan kakak iyel katakan kepada polisi

(pung, pung, pung, don't gossip (while pointing) it's not good, later opung and iyel's brother will tell the police)

Mona : apa katakan? Katakan apa?(tertawa) lapor iyel, lapor namanya. (what did you say? Tell me what? (laughs) report iyel, report name.)

Opung : mending kamu belajar lagi sana penggunaan kalimat, ngomong gak jelas aja sok sok mau lapor lapor, gossip lagi katanya (tertawa)

(you better learn how to use sentences, don't speak clearly don't pretend to want to report, gossip again (laughs))

Iyel : gossip, gossip, gossip kakak dan opung tidak baik! (dengan nada penekanan) (gossip, gossip, gossip, brother and sister are not good)

Opung : itu bukan gossip iyel tapi ngobrol, gossip itu kita membahas seseorang, ini kan kami ngborolin resep masakan, masak kamu kalau lihat orang ngbrol kamu anggap gossip, piye toh

it's not gossip, but talking, gossip is that we are discussing someone, this is how we share recipes, cook if you see people chatting, you think it's gossip, nope.

Iyel : (meninggalkan sambil merasa malu)

((leaving while feeling embarrassed))

From the conversation above, it can be seen that the imperative sentence works to give advice. The conversation above a ten year old child is giving advice to his grandma and sister not to gossip according to the child's way, it can be seen from the sentence "don't gossip", "gossip is not good" it can be seen that the use of sentences that are less mature for a ten year old child, receptive language disorder is very clearly visible, the limited vocabulary in Indonesian is visible, the ten years old child understands in English but does not know the real meaning in Indonesian, the use of the word is not right, it is contained in the sentence "later Opung and Iyel will tell the police" the meaning of the child was wanting to report, but the ten-year-old could not pronounce the sentence. And there is repetition of sentence.

\subsubsection{Interjective Sentence}

Interjective sentence is a sentence to express emotions, such as us surprised, amazed, angry, sad, frustrated. The interjective is more indicated by an expression that is sometimes not expressed in sentences.

Table 4. Interjective Frequency

\begin{tabular}{llcr}
\hline No. & Function & Frequency & Percentage \\
\hline 1. & Surprise & 5 & $23,8 \%$ \\
2. & Amazed & 3 & $14,3 \%$ \\
3. & Angry & 7 & $33,33 \%$ \\
4 & Sad & 5 & $23,8 \%$ \\
5. & Frustated & 1 & $4,8 \%$ \\
\hline & Total & 19 & $100 \%$
\end{tabular}


From the data above, it can be interpreted that angry expressions are the most in Yeriel, namely 7 data $(33.33 \%)$, surprise as much as 5 data $(23.8 \%)$, sad as much as 5 data $(23.8 \%)$, amazed as many as 3 data $(14.3 \%)$, Frustrated 1 data $(4.8 \%)$.

Below is an interjective sentence from a ten year old child who was caught through the expressions and sentences used. The situation below occurs when Yeriel is angry and enters the room, in the room there is a sister who is tidying the bedroom, for convenience the author gives the code $\mathrm{M}$ (Mona) and I (Yeriel).

Mei 08, 2021 at living room

M : kenapa pakaian nya kamu buang?

(why did you throw away the clothes?)

: aaaaarrgh (sambil menggengam tangan nya)

(aaaaarrgh (while holding his hand))

M : Kenapa kamu?

(what?)

I : iyel sangat marah, ah, hah, ih, argh salah dia.

(Iyel is very angry, ah, hah, uh, argh his mistake.)

M : papa mu yang buat marah, kenapa kakak yang nerima marah mu, ambil

bajunya.

(it was your papa who made you angry, why did your brother accept your anger, take the clothes.)

From the conversation above, it can be seen that the interjective sentence works as a sentence that shows an angry expression, a ten year old child is expressing his anger, it can be seen from the words "Arg" arg is a form of angry or annoyed expression, and seen from his body language where a ten year old child holding his hand, with several forms of expression such as "ah, hah, ih, argh".

The next conversation is interjective sentevce to express shocked or surprised, this conversation is taken when a ten year old child is in the kitchen and sees an insect that he doesn't like.

\section{Mei, $30^{\text {th }}, 2021$ in the kitchen}

Iyel : (sedang berjalan menuju dapur dan duduk di kursi makan)

((walks into the kitchen and sits on the dining chair)

Opung : Ngapain kedapur? sana diruang tv aja nonton

(Why the kitchen? there in the tv room just watch)

Iyel : iyel mau disini pung, ... (one minute latter)

WOW, AAH, WHAT, WHAT, tidak, ah, ah, ah kecoak kecoak kecoak (sambil melompat) (iyel want to be here, ... (one minute latter)

WOW, AAH, WHAT, WHAT, no ah, ah, ah cockroach cockroach cockroach (jumping))

Opung : kan opung sudah bilang jangan kesini

(I told you do not come)

Iyel

: iyel shocked, shocked, shocked

The next conversation is interjective sentevce to express shocked or surprised, this conversation is taken when a ten year old child From the short conversation above, the interjective plays a role in expressing surprise, the conversation above with several expressions that come out of his body, the feeling of surprise can be seen when a ten year old child says "wow, ah, what, no, ah,) and body expressions jump.

\subsection{Findings}

After analyzing the data, In this research finding, the researcher elaborated findings after analyzing the data, as follows:

From the results of the types analysis of the sentences produced by ten-year-old child, it was found that tenyear-olds were more dominant in interrogative that are 26 data $(34,6 \%)$ sentenences and the second is the imperative sentences that are 21 data (28\%), the third is interjective sentence there is 19 data $(25,3 \%)$, and the last is declarative sentence there is 9 data $(12,1 \%)$.

\subsection{Discussion}

The purpose of this study is to find out the Indonesian sentence by ten years old child with receptive language disorder. According to Aitchison (Haras and Andika (2009:50-56) said that ten years old child has matured in communication, and in this study the researcher is interested in children who are not too mature in the use of sentences. But we can not compare a child with the others in the process of acquiring the language because they have different factors. Some child faster, the other child slower. Uhame (2019) examined first language acquisition of Aitchison's early chilhood perspective, she describe in detail the phenomenon of early chilhood acquisition in everyday life, she findings that indicate that the language development by Aitchison consist in ten stage. Different from the results obtained in this study, this case the researcher found that Yeriel as a subject not too mature in language, due to several factors that prevent the child from acquiring his first language.

1. According to Chaer, 2009: 44) "The division of sentence is based on term of content is this division based on the content or man date to be conveyed to the listener". Based on the term of content or speech, sentence upon sentence is distinguished in declarative sentence, interrogative, imperative and interjective. Hepnyi (2018) examined language acqusition in Bahasa Indonesia: a case study on 4 years old childrent. This study aims at tracing the first language acquisition of two children at age 4 , she 
conducted based on naturalistic observation. She findings that the child seems to be able to use sentences having grammatical features corresponding to adult language and master declarative, negative, imperative and interogative. In this research About question one, therefore interrogatives are much more than other sentences that is $26(34,6 \%)$. Because at their age, which supports children in asking a lot of questions, the question that is often used is the question "why". The second is an interjective sentence with the form of expression where the most frequently used are angry and surprised that is $21(28 \%)$. And the third is the imperative sentence and the one that comes out the most is imperative for commands, warnings and advice that is $19(25,3 \%)$. And the last one is Declarative sentences $9(12,1)$ the most frequently is To make decision. Because seeing the ten-year-old child is a child who doesn't care and rarely declares something.

\section{CONCLUSIONS AND SUGGESTIONS}

\subsection{Conclusions}

Based on the research findings, some conclusions are drawn as the following:

1. From the results obtained from the types of sentences, it was found that children with language disorders greatly affect the form of senteces produced. The ten-year-old's weakness in speaking Indonesian makes the child different when communicating with the surrounding environment. From the results found, the interrogative sentence was the sentence that was found the most, seeing the age of the child who was in a period of wanting to know many things. And the least used is the declarative sentence because the child is less interested and weak in giving statements and describing things. The conclusions obtained are related to the theory from Aitchison (1984) which says that 10-yearold children are very mature in language, and the results of this study found that ten-year-olds are not too mature in language.

\subsection{Suggestions}

In relations to conclusion, suggestions are staged as the following:

\section{To the parents}

Parents have a very important role in language acquisition, it is hoped that through this thesis parents will pay more attention to the acquisition of children's language, especially for Indonesian as the mother tongue. Parents must be more creative in providing stimulus to children in an effort to improve the quality of their child's language, and be able to balance the ability of the child's second and first language to prevent children from experiencing language disorders.

\section{To other researcher}

It is suggested that further studies should be conducted to find out more types of Indonesian sentence child who have language disorder in the some age. that further studies should be conducted to find out more process of sentence acquisition in the different context. Other researcher should be conducted study to find out more factors affect language acquisition and about the social interaction theory, because interaction is the important for child to get mature language.

\section{REFERENCES}

[1] Chaer, A. 2009. Sintaksis Bahasa Indonesia (Pendekatan Proses). Jakarta: Rineka Cipta.

[2] Clarck E.2003. First Language Acqusition. United Kingdom : Cambridge University Press

[3] Clark, E, V. \& Clark, H.H 1997. Psychology and Language :An Introduction to Psycholinguistic : Cambridge University Presss

[4] Dardjowidjojo. Soenjono. 2005. Psikolinguistik Pengantar Pemahaman Bahasa Manusia. Jakarta: Yayasan Obor Indonesia

[5] Dirgeyasa. I Wy. 2019. The Art of Scientific Writing. Medan : Fbs Unimed Press

[6] Darjowidjodo, S. 2000. ECHA :kisah pemerolehan bahasa anak Indonesia. Jakarta.Grasindo Jaya.

[7] Erillia, R. May 2011. Pemerolehan dan Proses Perkembangan Bahasa Pada Anak. Retrived from http://kikynabiby.blogspot.co.id (May 2017)

[8] Herschensohn, J. 2007. Language Development and Age. New York, Cambridge. Univesity Press.

[9] Kridalaksana. H. 1993. Kamus Linguistik. Jakarta:Gramedia

[10] Kholid A.H. \& Andika D.B. 2009. Dasar-Dasar Psikolingusitik ; Universitas Pendidikan Indonesia Press

[11] Marshall,Chaterine \& Gretchen B. Rossman. 1995. Designing Qualitative Research. London:Sage

[12] Miles,Matthew B. and Huberman Michael A. 1984.Qualitative Data Analysis. A Sourcebook of New Methods. California : Sage Publication.

[13] Mehrpour, S. and Forutan, A. 2015. Theories of First Language Acquisition, Vol. 1 No. 2. Iran: American Institute of Science. 